\title{
Translation and Enculturation as a Process of Acculturation
}

\section{Turgut Gümüşoğlua}

\begin{abstract}
When we look through the world history, it can be seen clearly that language has a great role on culture, arts, and social movements, and the translation is an important player in this context. A commonly shared European culture together with its values has emerged as a product of such sociolinguistic dynamics. Following these encounters, whether at word borrowing level or morpho-syntactical level, European languages have had positive and/or negative effects on each other and have evolved ever since in this way as they have permeated themselves into culture. From the point of view on translation's intermediary role in enabling interaction between cultures throughout the history, the aim of the present study is to problematize the answers to the following questions: What are cultural ramifications that stem from linguistic encounter? What are the contributions of translated language to acculturation and enculturation processes? Can the new information through translation produce a culture translation phenomenon? How the hybrid understanding functions? Translation itself is a language encounter that makes impact on targeted languages as well as on its source. In this study, the dynamics that form this encounter space as a meta textual phenomenon has been problematized.
\end{abstract}

\section{Keywords}

Cultural translation, culture and language contact, sociolinguistics, transit place

When we look at the world history from present to past, how great the importance of language in terms of culture, art, and social movements and thus the importance of translation is well construed. Riel considers Europe's current language as a result of the encounter of languages and thus the encounter of cultures during the historical process (Riel 2004: 171). Mutual European culture and values appear as a product of the sociolinguistic dynamics. Throughout the history as a result of all these encounters, languages have been affected (positively/negatively) ${ }^{1}$ by each other in terms of both borrowing and morpho-syntax and have reached today as a part of the cultural life (Gümüşoğlu 2010: 58-70).

This study will try to problematize the answers of the following questions related to the role of translation as a cross-cultural tool of interaction in the history to this day :

(1) What are the cultural reflections of translation as a result of encounter of languages?

(2) What is the contribution of the translation language to the acculturation and enculturation process?

(3) Is the new knowledge achieved through translation, able to produce the case of culture translation? If so, how does it manage to do so?

astanbul University, Turkey

Correspondent Author:

Turgut Gümüşoğlu, Edebiyat Fak. Ordu Cad 196, Laleli, Istanbul

E-mail: t_gumusoglu@hotmail.com 
The translation itself is a language encounter phenomenon and it has an impact on both its source language and the target languages. According to Delisle and Woodsworth, the translators "have helped to develop systems of writing, in their efforts to bring certain fundamental texts from one culture to another, they have also had an impact on the evolution of language itself" (Delisle and Woodsworth 1995: 25). It is obvious that Hieronymus's Vulgata in the fourth century and Martin Luther's Bible in the sixteenth century caused the collapse of and a diversity in social dynamics in Europe. All of these, as mentioned above, are the encounter of cultures, in a sense, an encounter of languages realized through the transfer from one language into another. The importance of translation, in other words, the new knowledge through translation, seems to have triggered the formation of new ideas about the target language. While the translation of Ancient Greek works into Arabic had played a great role in illuminating Islam in the tenth century, conversely, the translation of Arabic works into Latin played its own role in the illumination of Europe in the thirteenth century. According to Gutas, "The Greek-Arabic translation movement has started a new era in the history of humanity. The translation movement has the same importance with Pericles's Athens, Italian Renaissance or the sixteenth and seventeenth century scientific revolution (...) " (Gutas 2011: 20). The Ecole des Enfantsde Langue (School of Language Boys) founded in Istanbul in the seventeenth century was not only a translation activity, in a sense, it was also the pioneer of social dynamics that approached European and Ottoman-Turkish cultures to each other. As a result of these encounters of culture language translation, many works have been translated across cultures and during this process, values and life styles of different cultures have been transferred across cultures alongside the language (Gümüşoğlu 2015). "Thanks to the translation activity which is an inseparable part of multiculturalism, along with language, cultural encounter and synthesis areas have arisen" (Eruz 2010: 14). The most notable example for this is Europe's encounter with coffee and tulip. While the West adopted these through translators, tulips became one of Netherlands's most important economical occupations and along with coffee, cafés emerged and became a place where people get together, talk about politics, and get to know each other.

Translation and national identity have a connection as strong as the one between translation and multiculturalism. According to Even-Zohar, national culture and identity have a direct relationship built by translation (Even-Zohar 1987). Ülken states that one of the most important means that led to the formation of nations is the translation that "takes part in the awakening periods". This awakening has two reasons: "Firstly, translation provided the continuity of thought, just like it did in every awakening period. Secondly, language is the chief point in national awakenings (...) and the desire to express in native language" (Ülken 2009: 221). With reference to this quotation, it is emphasized that translation has a triggering role in the development of the national language as a culture conveying factor. The reason behind the selected translation of world literature widely undertaken in the 1940s was not just to translate them for the people to read. Kurultay states that there was "no such initiative with such spirit" before, and the translation movement supported by the government "strengthened the culture references of this incoming tendency" (Kurultay 1999: 25).

Like almost every twentieth century highbrow, Halide Edip Adivar also emphasized the importance of the nation formation process, modernization, westernization - a necessary step in the historical process, and she attaches great importance to translation in this process. According to Adivar, pre-nineteenth century Turkish literature was under the influence of the East and especially of the Persian philology. On the other hand, the nineteenth century 
was influenced by the West and especially by the French. However, the important points are the problems about the translation method and not whether the translation is made from the Western or Eastern sources. The highbrows did not translate the works, on the contrary, they appropriated the munder the Farsi influence, as a consequence, a diglossia language appeared between the highbrows and the public, and this process has affected the development of Turkish literature and language negatively (Adivar 1944). She also states that the East affected even the translations from the West, and it was far from the logic of nationalism created by the French Revolution. Therefore, such a dynamic does not exist in translations. She mentions that real translation which emphasizes creativity, started at the Republican period. The translations in different subjects and from various languages during the Republican period are of great importance compared with Pre-republic translation effort which was monopolar and undertaken under the dominance of other cultures, but she states that the inappropriate construction of translation strategies created by these differences may affect the existing cultural dynamics in a negative way. According to Adivar, what important is to develop a translation strategy appropriate for the target culture. Thus, positive and healthy translation will be achieved. This translation strategy is defined by Ülken in these words: "Translation is like sewing a new dress: Your translation should not reveal the stiches" (Ülken 2003 34-53).

While mentioning the influence of translation on culture, Engünün remarks that translation plays a great role in the cultural and therefore intellectual transformation. The culture and language encounter impresses reformist and developmentalist ideas on the community entered, through translation (Engünün 2011). Unlike Adıvar, Engünün mentioning the positive influence of translation, states that a culture proceeds by the knowledge received through translation from a more developed culture and that is how civilizations are formed. Ülken equates cultural encounter and cultures' knowledge about each other to development. According to Ülken, Ottoman and other cultures like Indian and Chinese, completed their lifetime by closing the gates to the outside world. On the contrary, the West was always able to proceed as it was always open to cultural dynamics (Ülken 2009). Although Engünün affirms Tanzimat translation movements, Ülken expresses that it was far from Bagdad, Toledo, or Renaissance translation movements. Ülken regards them as "incomplete, hurried, random translations" and they only covered daily necessities and most importantly the mistakes in translation strategies in the cultural background of the target culture are the main reasons for failure (Ülken 2009). The language of translation and the people perceiving the translation were ignored.

Even-Zohar's culture repertoire term may enlighten what Adıvar and Ülken are trying to express. Ülken concentrates on randomness, because of what happened in achieving the compliance between source and target for both center-periphery and forming a systematical background during the import and transport, translation did not achieve the desired level (Even-Zohar 1987: 166-174). Karadağ analyzing the translation—departing from Ülken, both the approach to retranslate the translated works and the dialog and debate platform between the Eastern and Western civilizations - from the Ottoman to these days, "the translation adventure" of Robinson Crusoe first being translated from Arabic and then from French, indicates that this translation movement is not a coincidence. After the Arabic translation, the reason to choose to translate from French-which represents the enlightening Western culture-rather than the original English, represents a type of Western emphasizing individualism and civilizing its surroundings (Karadağ 2008: 179-181).

Ülken states that the civilizations may keep existing as far as they are aware of and interact with 
each other and for that translation is the essential trigger: "Ancient Greek awakening was actualized by the Anatolian, Phoenicia, Egyptian translations; the Turk Uyghur awakening by Indian, Persian, Nestorian translations; the Islam awakening by Greek (Nestorian, Jacobite), Indian translations; the New West awakening by Islam (Turkish, Arabic, Persian), Jewish, Greek translations" (Ülken 2009: 5). For him, translations triggered the awakenings. However, Kurultay mentions that awakenings were triggered by those who did the translations and so one cannot ignore that an appropriate setting had already existed.

According to Kurultay, "Ülken's statement 'Translation provides the power of creation during awakening periods' (Ülken 2009: 14) may not be wrong but is arguable. It is quite misleading to say that translation begins the awakening. Because the precondition of translation is the individuals who already have awakened and opened to the outer world" (Kurultay 1999: 35). In this sense, the periodical translation movements are social, political, and cultural oriented complex language culture phenomenon. Considering the Abbasid translation movement, it is obvious that the region is not unfamiliar with translation. The Greek works had already been translated to Syriac in the monasteries, but there were not many Syriac texts with non-religious content and so it was fastened by the Abbasid translation movement (Gutas 2011: 33). Gutas expressing that during Abbasid period, there were many factors fastening the translation movement, remarks that the government was aware of the importance of reaching the knowledge as a state ideology to be powerful in all aspects and its way passing through translation. In this period, translation reveals two basic demands that can answer new social dynamics: Firstly, learning the knowledge to fulfill the needs; secondly, gaining the theoretical knowledge that will form the basis of the incoming science and philosophy (Gutas 2011: 108). This knowledge achieved through translation enabled the birth of a new science culture. The transfer of knowledge scientific occupations on the translated fields provokes the creation of authentic and critical works. By the retranslation of the old translations, arguments on translation errors and knowledge always preserved their vitality. During this period, many new works that exceeded the translated works were produced and an enlightening role was put to the other cultures.

Ülken notes that the creation era of Islamic period is between the tenth and twelveth centuries, as for the Ottomans, there was no translation activity until the eras of Mehmet II and Beyazid II. However, he also adds that this translation movement was stopped due to some social movements and therefore tension by introversion appeared (Ülken 2009). Therefore, the Western awakening did not occur until the translation of Islamic philosophical works into Latin. "Islamic philosophy growing after twelveth century began a great translation movement by entering the West through Sicilia and Andulusia" (Ülken 2004: 269-294). $\mathrm{He}$ notes that in the eighteenth century, German philosophy and cultural development overdid the translation so that the Germans became "French's toy as Logoa puts it" (Ülken 2009: 226), but a while later, people like Goethe, Kant, and Beethoven were born. As Ülken puts it, another important reason why Germans are beyond the other Western societies in terms of thought is that "Unlike its Greek and Latin roots, it is unfamiliar with language and traditions, so this gap was filled only with great translation and transfer" (Ülken 2009: 228-231). Ülken linking Ottoman downfall with the connection break between old and new civilizations which led to the loss of creativity, mentions the thought anesthesia they were in. He also adds that Russia is one of the latest nations meeting translation and with the foundation of "Russian language loving society" in 1735, many Western works began to be translated into Russian - even if it was by imitation - and in terms of culture, a very fast development could be observed (Ülken 2009). 


\section{THE TRIGGER OF TRANSLATION}

Putting aside the fact that translation in history lost its cultural-linguistic-functional worth in classical sense, its evolving role through the change of social dynamics is observable. The languages, with the effect of transnationalism, transcultural, allochthonous, European Union language and translation policy and the media, have gained a larger ground than ever before. These all trigger translation. Not only the awakening periods, but also socio-economic dynamics and crises increase translation activity in terms of both quality and quantity. For instance, as a result of the economic crisis in Greece, its socio-economic relations with Turkey have increased. Aside from the translation activities borning from economic relations, the translation of popularizing and increasing Turkish TV series and the cultural translations (TV series, social TV shows, magazines and book translations, symposiums, etc.) created, provided the formation of some new social dynamics. Works like Harry Potter that are published in English worldwide, simultaneously reach their readers in Turkish. With the impact of Turkish immigrants, mutual translation activities have been accelerated German-speaking countries. In this sense, Dizdar remarks that the translator is an immigrant between two cultures, transforming culture and languages (Dizdar 2008: 96). Translation with globalizing media, unlike its previous basic role, appears as a popularizing consumption tool. The increasing number of foreign language speakers and the possibility of education in foreign languages at the universities increase cultural translation activity. However, the experience of foreignness has two basic contingencies, the individual's foreignness to other languages and cultures, and on the other hand, the foreignness of others. The experience of both occurs by language (Mae 2010: 36). Sayın observing a directly proportional connection between foreign language acquisition and translation activity, notes that the limitedness of an individual is by language and during the foreign language acquisition process, his individual limits extend and he opens himself to the world. In this sense, since people cannot learn all languages, translation has an important function in surpassing the limits (Sayın 2000: 98-104). Foreign language and translation based on the power hegemony, inexpression and the inability to translate the intended in source language into the target language may reproduce a crisis. As long as this crisis produces new syntheses, we can talk about the existence of cultural translation. Otherwise, it may result in culture importation rather than cultural translation. And it produces an imitated culture where creativity ceases to exist and where it is impossible to mention any kind of translation.

Kupsch-Losereit remarking the cultural dynamic of translation observes translation as a bicultural event and says the values of source and target cultures should be considered while translating. In this sense, translation is a special kind of intercultural communication (Kupsch-Losereit 1995: 2). Therefore, in order to understand the text to be translated besides the conditions of text-linguistics, the place and time the text was produced, the sociocultural conditions of language in the target culture, and the cultural reception logic should be regarded. The skopos of translation studies, in other words its aim and function so it can be functional and target audience oriented activity - because source and target cultures are not the same - is to place it to the culture of translated language (Koller 2001: 123).

Languages and cultures form meeting points that affect acculturation dynamics both in and outside nation states. This meeting point reproduces areas of encounter and translation is a cultural-linguistic activity formed in this area of encounter. This activity affects individuals and communities at global platform as an acculturation tool. The terms below are factors influencing the translation dynamics during acculturation: 
(1) The increase of foreign language;

(2) Migration (education, business, international companies, and tourism);

(3) Socio-economic crisis;

(4) Media;

(5) University;

(6) Popular-culture-consumption.

As mentioned above, translation as a process of acculturation occurs in the area of encounter. No matter how this area of encounter is called third space (Bhabha 2008; Wolf 2010) or culture repertoire (Even-Zohar 1987) - basically there is a minority culture opposing monoculture and a hybrid (Pahor 2008) environment established between them. The area of encounter is a process and new syntheses are produced. Sociologically, it is the area where cultural production reaches the peak point, rather than a tension and a crisis area. In this sense, knowledge is formed transculturally in the area of encounter and becomes more valuable and powerful beside the old. Today, culture is formed in the third space-the meeting and transform point of differences, and in this sense, the reestablishing area-rather than traditional culture theory limited traditions. "The transitionality of difference"- the most important player of hybrid creation, in other words, translation is also established in this area (Bhabha 2000). Therefore, translation is the totality of the creative activities contributing to the creation of cultural values rather than a bridge between two cultures. The third space, a flexible platform with intensive change, covers the dynamics resulted from migrant identity, foreign and transnational life styles, and these relations (Kliems 2007: 31). This way, observing the world in the eyes of others and in this sense, a new point of view of others will be achieved in this area (Kuruyazıc1 2011: 210-213). Through the achieved translations, writers by being vitalized in the other culture, will cross the borders between two cultures and will be fictionalized again in the translated language (Kuruyazıc1 2011: 212).

During this fiction process, the imitation - in other words, the translated has no responsibility toward the original in the third space in installation phase. In this process, imitation is new and continuously transforming due to its hybridity. It is a continuous tendency, the living space of breaking and crises, finding itself in migration dynamics. In this sense, migration culture and transnational identities are translation in the flesh (Bhabha 2000). Original and imitation promoting foreignness in the new culture creation should be sensed in the translated language. Cultural translation is both metaphorically transferring the transferable from one culture to the other living space, and making cultural contents perceived during translation (Wolf 2011: 176). In these areas of encounter formed especially for reasons like migration-as a process an individual translating itself (Vorderobermeier 2008: 39)—while foreign language coincides with an individual's own language, his own language starts to alienate and metamorphose (Wolf 2008: 29). In this sense, acculturation with respect to social political dynamics in the third space and with the oppression or creativity of identity forming elements will positively provoke identities. Otherwise, assimilation would be a matter and hybrid identity would turn into otherness and foreign identity as a reflection of a problem. As mentioned above and also by Adivar, this is called negative translation. There is no creativity and reproduction, the culture became an imitation and could not be translated.

Departing from what was discussed above, translation is comprehended as a process of knowledge acquisition, recognition, defining, and acculturation. How can enculturation and acculturation, as terms based on sociology, be studied in terms of translation?

\section{TRANSLATION AS A CULTURAL TRANSFORMATION}

Cultural contact and language contact are the leading crucial mechanisms of culture formation, development 
and in time even the disappearance of a culture opposing another culture. According to Bhabha, culture is both transnational and translational (Bhabha 2000). Cultures are not unattached to each other and on the contrary as a result of the relationships with each other, they achieved their present forms and formed cultural living space called civilizations. By contrast with Huntington's civilization conflict, civilizations achieved their present forms as a result of cultural contact, as justified by Said. Therefore, people need translation to transfer the foreign culture to themselves and to transfer theirs - this contact is obligatory - to foreign cultures and by this means civilizations are formed (Mudersbach 2001: 191). This never-ending process constantly creates new syntheses in motion and this way, affects and transforms societies and individuals within. The leading dynamics of this transformation tool are, migration and speaking the language of the other culture as a communication tool, and in this sense, the translation activities in order to understand the present knowledge in that language. The basic mechanism enabling the interaction between two cultures is language and that language has a role in the determination of cultural dynamics, as they are in socio-political dynamics of the period. According to Göktürk, every new translation not only affects the present settled tradition, but also adds creativity by affecting the literary text tradition of the translated language. Since translation will be evaluated in the cultural context of the period, depending on this effect, the language is affected too (Göktürk 2000: 95).

Individuals join the society and the culture with a complex socialization mechanism. Consciously or unconsciously, an individual is brought into the society with these enculturation tools and continuity is maintained. While existing cultural values are transferred to the individual, this social situation containing the subjects-classes, statuses, and ideologies, adds the values of the tradition to its subjective experience and by synthesizing - even if it is limited-joins the society. The process of joining the society basically is formed as dichotomous: both conservative and reformist. According to Reinhold, Lamnek, and Recker (2000), enculturation is any kind of values an individual unconsciously perceives in the society by socializing. The individual automatically adopts the values (language, morality, religion, custom, behavior, respect, etc.) he received from the society he lives, and joins the social life through cultural-values-acquisition process (Reinhold et al. 2000: 140). In this sense, enculturation is not only a contact of the individual with social dynamics in a homogenous culture, it also forms a new society which accepts the new social values and meets the socialization process in the contact with the new social dynamics that he enters as a foreigner in a different culture. This connotative term of sociology, contains many meanings like integration or assimilation. The term of enculturation here is considered, in terms of translation studies, as a cultural input as a social transformation tool. The new inputs (language, values, style, behavior, etc.) will take part in changing and transforming the society's cultural dynamics through translation. While an individual and a society encounter each other or another culture, apart from enculturation, acculturation also takes place. Sociology defines acculturation as a totally different identity formed as a result of the interaction between different cultures. This interaction causes cultural transformation. With the incoming inputs, the individual and the society transform due to these new values. According to Reinhold, acculturation is: (1) the social transformation-the reception and the adoption of the foreign culture - of the individuals and the social groups as a result of encounter; (2) the reception of cultural values by the other culture; and (3) the transfer as a socialization tool, in the same culture with enculturation, among generations (Reinhold et al. 2000: 10).

Acculturation is a two-dimension process. On the one hand, the existing values are maintained; on the 
other hand, a new synthesis is created by receiving the values of the prestigious, popular or lately entered culture. There are four acculturation strategies that migration sociology especially remarks: integration, assimilation, segregation, marginalization (Berry et al. 2011). The integration process - the much-debated term, encountered especially after migration-is defined as protecting one's own culture and not being closed toward new values, in other words mutual interaction (Gümüşoğlu et al. 2009). The loss of cultural values and adopting the new culture are assimilation, on the contrary, protecting cultural values and also maintaining a life refusing social interaction are defined as segregation. Both protecting cultural values and accepting social communication form marginalization. However, the studies performed on different migration groups show that these terms' meanings may change according to cultural environments and the processes the migrants have been through (Gümüşoğlu et al. 2009).

As a result, with the effect of different social dynamics, translation has had different meanings throughout the history. It is explicit that translation has a specific role, a positively or negatively changing and transforming influence. Therefore, cultural translation is considered as the translation of all foreign textual and non-textual tools in target culture. Thus, new behaviors will be produced in the target culture. These new behaviors as an acculturation process will influence both the source and the target culture. Cultural translation is not one-way and the concept itself is influenced by this influencing process while influencing others. This interaction process generates acculturation in the area of encounter. However, acculturation, during this process with specific stages to pass, shows mostly a positive development. The other way around is also possible. The stages below will form this process.

Firstly, it is important where (third space, hybrid culture, etc.) the area of encounter was formed. Linguistic-cultural areas of encounter occur in many different areas and conditions like migration, transnationalism, exploitation, minority, dominant culture, symposium, emergency case, etc. Secondly, in this stage, the area of encounter puts itself to the area of translation and the reservoir of existing values takes place with social factors/culture carriers. The third stage consists of culture translation strategy. At this stage, first the translation triggering mechanism and then the compliance mechanism step in as translation strategies. In this sense, translation has a result in terms of why has the translation activity occurred, what were the influences (triggers) and if compliance (acculturation) has occurred or not. The fourth stage includes positive and negative culture translation. Negative culture translation is caused by untranslatability. The dominant culture has injected its values one way or another. The target culture has perceived them, but its own existing cultural reservoir almost disappears and the original is replaced by imitation. Just as the existing values could not be maintained, as a result of the influences entering through translation deconstruction and alienation took place. The negative cultural translation-due to the fact that compliance and synthesis could not be formed basically is the product of the result of untranslatability. The dominions, the third world countries, and Central Asia republics are personifications of this situation. What kind of culture repertoire did these countries form in the context of center-periphery? Have all the inputs coming from the center been able to be translated into these countries? The answers for these questions can be seen if looked at the present situation of these countries. On the other hand, positive culture translation consists of mutual interaction. This interaction triggers creativity and enables the birth of new ideas. The Western European culture may exemplify this.

The new dynamics formed in areas of encounter which are culture translation areas-in case of compliance-will increase social awareness by creating new syntheses. 


\section{CONCLUSIONS}

In conclusion, translation as a process of knowledge acquisition, recognition, defining, and acculturation, transforms the societies and creates encounter spaces in which they interact with each other, creating new dynamics through translation. These dynamics formed in areas of encounter-which are culture translation areas - will increase social awareness by creating new syntheses.

\section{Note}

1. When languages and cultures encounter, they have a bearing on each other; these encounters may as well lead to a syntheses just like they may cause assimilation at times, depending on quite complex socioeconomic or political reasons.

\section{References}

Adıvar, H. E. 1944. Edebiyatta tercümenin rolü (The Role of Literature in Translation). İstanbul: Kenan Matbaas1.

Berry, J. W., Y. H. Poortinga, S. M. Breugelmans, A. Chasiotis, and D. L. Sam. 2011. Cross-Cultural Psychology. Cambridge: Cambridge University Press.

Bhabha, H. K. 2000. Die Verortung der Kultur (Emplacement of Culture). Tübingen: Stauffenburg Verlag.

Delisle, J. and J. Woodsworth. 1995. Translators Throught History. Paris: UNESCO Publishing.

Dizdar, D. 2008. "Die Mutterzunge drehen. Erfahrungen aus und mit einem Text" (Turn the Mother Tongue. Experiments From and Within a Text). In "Meine Sprache grenzt mich ab...”: Transkulturalitaet und kulurelle Übersetzung im Kontext von Migration ("My Language Fences Me off...": Transculturality and Cultural Translations Within the Context of Migration), edited by G. Vorderobermeier and M. Wolf. Berlin: LIT.

Engünün, İ. 2011. "Tanzimat sonrast çeviriler" Mukayeseli Edebiyat ("Translations After the Tanzimat Reform Era" Comparative Literature). İstanbul: Dergah yayınları.

Eruz, S. 2010. Çokkültürlülük ve çeviri: Osmanlı Devleti'nde çeviri etkinliği ve çevirmenler (Multiculture and Translation: Translators and Translation Activity in Ottoman Empire). İstanbul: Multilingual.

Even-Zohar, I. 1987. The Making of Culture Repertoire and the Role of Transfer: (Re)shaping of Literature and Culture. İstanbul: Boğaziçi Üniversitesi Yayınlan.
Göktürk, A. 2000. Çeviri: Dillerin dili (Translation: The Language of Languages). İstanbul: YKY.

Gümüşoğlu, T. 2010. Sprachkontakt und deutsch-türkisches Code-Switching: Eine soziolinguistische Untersuchung mündlicher Kommunikation türkischer Migrantlnnen (Language Contact and German-Turkish Code-Switching: A Sociolinguistic Study of Oral Communications by Turkish Migrant). Frankfurt am Main: Peter Lang.

- 2015. "Sprachknaben: Die wahre Brücke zwischen Orient und Okzident" (Dragoman: The Real Bridge Between Orient and Occident). Pp. 141-152 in Cross Cultural Communication, edited by E. W. B. Hess-Lüttich and Y. Takahashi. Frankfurt am Main: Peter Lang.

Gümüşoğlu, T., M. Batur, H. Kalayc1, and Y. Baraz. 2009. Türkische Migrantlnnen in Osterreich: Eine Querschnittstudie der türkischen Migrantengemeinschaft zwischen Struktur und Integration (Turkish Migrant in Austria: A Study of Turkish Migrant Society Between Structure and Integration). Frankfurt am Main: Peter Lang.

Gutas, D. 2011. Yunanca Düşünce Arapça Kültür: Bağdat'ta Yunanca-Arapça Çeviri Hareketi ve Erken Abbasi Toplumu (Greek Idea Arabic Culture: Greek-Arabic Translation Activity and Pre-Abbasid Society in Bagdad). İstanbul: Kitap Yayınevi.

Karadağ, A. B. 2008. Çevirinin Tanıklı̆̆ında Medeniyetin Dönüşümü (Transformation of Civilization in the Witness of Translation). İstanbul: DİYE.

Kliems, A. 2007. "Transkulturalität des Exils und Translation im Exil. Versuch einer Zusammenbindung" (Transculturality in Exile und Translation on Exile. An Attempt to Correlate). In Übersetzung als transkultureller Prozess (Translation as a Transcultural Process), edited by C. D. Krohn, E. Rotermund, L. Winckler, W. Koepke, and M. Enderle-Ristorie. Tübingen: Laupp \& Göbel.

Koller, W. 2001. Linguistik und kulturelle Dimension der Ubersetzung - in den 70er-Jahren und heute (Linguistics and Cultural Dimension of Translation-In the 70s and Today). Pp. 115-130 in Kultur und Ubersetzung. Methodologische Probleme des Kulturtransfers (Culture and Translation. Methodological Problem of Cultural Transfer), edited by G. Thome, C. Giel, and H. Gerzymisch-Arbogast. Tübingen: Gunter Narr Verlag.

Kupsch-Losereit, S. 1995. "Übersetzen als transkultureller Verstehens-und Kommunikationsvorgang: andere Kulturen, andere Äußerungen" (Translation as a Transcultural Understanding-And Communication Event: Other Cultures and Other Utterance). Pp. 1-15 in Sprachtransfer-Kulturtransfer (Language Transfer, Cultural Transfer), edited by N. Salnikow. Frankfurt am Main: Peter Lang.

Kurultay, T. 1999. "Cunhuriyet Türkiyesinde çevirinin ağır 
yükü ve Türk hümanizmi” (Turkish Humanism and the Burden of Translation on Turkish Republic). Journal of German Literature 13-37.

Kuruyazıc1, N. 2011. "Inwiefern dient die Ubersetzung der deutsch-türkischen Literatür (zu) einem Kulturtransfer" (To What Extent Does German-Turkish Literature of Translation Help Culture Transfer)? Pp. 176-182 in Turgay Kurultay'a bir armağan. Çeviribilimden kesitler. Ein Kaleideskop der Translationswissenschaft. Festschrift für Turgay Kurultay (A Gratuity to Turgay Kurultay. A Cross Section of Translatology. A Caleidoscope of Translatology. Collection for Turgay Kurultay), edited by S. Eruz and F. Şan. İstanbul: Multilingual.

Mae, M. 2010. "Tawada Yokos Literatur als kulturelles Übersetzen durch Transformation" (Tawada Yokos Literature as a Cultural Translation Between Thought Transformation). Pp. 34-43 in Übersetzung-Transformation (Translation-Transformation), edited by H. Yamamoto and C. Ivanovic. Würzburg: Verlag Könighausen \& Neumann.

Mudersbach, K. 2001. "Kultur braucht Ubersetzung. Übersetzung braucht Kültür (Model und Methode)" [Culture Needs Translation. Translation Needs Culture (Model and Methods)]. Pp. 115-130 in Kultur und Ubersetzung. Methodologische Probleme des Kulturtransfers (Culture and Translation. A Methodical Problem of Culture Transfer), edited by G. Thome, C. Giel, and H. Gerzymisch-Arbogast. Tübingen: Gunter Narr Verlag.

Pahor, M. J. 2008. "Transkulturation und Hybriditât im Spiegel der Migration. Das Beispiel Triest” (Transculturation and Hybridity in Mirror of Migration. An Example Triest). In "Meine Sprache grenzt mich ab ...": Transkulturalitat und kültürelle Ubersetzung im Kontext von Migration ("My Language Fences Me off...": Transculturality and Cultural Translations Within the Context of Migration), edited by G. Vorderobermeier and M. Wolf. Berlin: LIT.

Reinhold, G., S. Lamnek, and H. Recker. 2000. Soziologie-Lexikon (Sociology-Lexicon). München/Wien: Oldenbourg.

Riel, M. C. 2004. Sprachkontaktforschung: Eine Einführung (An Introduction to Language Contact Researching). Tübingen: Narr.

Sayın Ş. 2000. Border Over Stepping and Crosswalk. İstanbul: Multilingual.

Ülken, H. Z. 2003. Şeytan'la konuşmalar (Speaking With Devil). İstanbul: Ülken Yayınları.

_. 2004. Eski Yunan'dan çă̆daş düşünceye doğru İslam felsefesi. Kaynaklarl ve etkileri (Islamic Philosophy From Ancient Greek to Contemporary Idea. Resource and His
Efficiency). İstanbul: Ülken Yayınları.

—. 2009. Uyanış devirlerinde tercümenin rolü (The Role of Translation on Period of Awakening). İstanbul: Türkiye İş Bankası Kültür Yayınları.

Vorderobermeier, G. 2008. "Migration als Ubersetzung: Versuch einer Annäherung aus soziokognitiver Sicht" (Migration as a Translation: An Attempt to Approach of Socio-Cognitive View). In "Meine Sprache grenzt mich ab ...": Transkulturalitat und kültürelle Ubersetzung im Kontext von Migration ("My Language Fences Me off...": Transculturality and Cultural Translations Within the Context of Migration), edited by G. Vorderobermeier and M. Wolf. Berlin: LIT.

Wolf, M. 2008. "Zur kulturellen Ubersetzung der Migration: Theoretische Vorüberlegungen" (About Cultural Translations of Migration: Theoretical Pre-thought). In "Meine Sprache grenzt mich ab ...": Transkulturalitat und kültürelle Ubersetzung im Kontext von Migration ("My Language Fences Me off...": Transculturality and Cultural Translations Within the Context of Migration), edited by G. Vorderobermeier and M. Wolf. Berlin: LIT.

- 2010. "Kulturelle Übersetzung"-Spielweise für übersetzerische Beliebkeiten oder Spielarten von Übersetzung "nach Babel" ("Cultural Translations"-Gameway for Translatical Preference or Game Variety of Translation "to Babel")? Pp. 44-56 in Übersetzung-Transformation (Translation-Transformation), edited by H. Yamamoto and C. Ivanovic. Würzburg: Verlag Könighausen \& Neumann.

_. 2011. "Die Karavvanserei: Ort der Ubersetzung" (The Caravanserai: Place of Translation)? Pp. 176-182 in Turgay Kurultay'a bir armağan. Çeviribilimden kesitler. Ein Kaleideskop der Translationswissenschaft. Festschrift für Turgay Kurultay (A Gratuity to Turgay Kurultay. A Cross Section of Translatology. A Caleidoscope of Translatology. Collection for Turgay Kurultay), edited by S. Eruz and F. Şan. İstanbul: Multilingual.

Woodsworth, J. 1999. "Geschichte des Übersetzens" (The History of Translation). Pp. 39-43 in Handbuch Translation (Handbook Translation), edited by M. Snell-Hornby, H. G. Hönig, P. Kußmaul, and P. A. Schmitt. Tübingen: Stauffenburg.

\section{Bio}

Turgut Gümüşoğlu, Ph.D. in applied linguistics, assistant professor, İstanbul University; research fileds: sociolinguistics, sociology, linguistics, and translatology. 